УДК 930.2:(477)+[(438)+(439)+(437.1/2.)+(437.6)]"19"

DOI 10.31.65/2520-6966-2020-13i-99-133-143

\author{
А. Л. Кавунник \\ здобувач Інституту української археографії та \\ джерелознавства ім. М. Грушевського НАН України \\ ORCID 0000-0003-4920-2327; e-mail: kavunnyk.a@gmail.com
}

\title{
Регіональні аспекти міжнародної політики Європейського Союзу в контексті "Східного партнерства"
}

У статті в контексті історичних фрактів з минулого та сьогодення України, країн-учасниць ініціативи ЄС "Східне партнерство" розкрито регіональні аспекти міжнародної політики країн Співдружності. Стверджено актуальність дослідження документальних джерел, соціокомунікативного, територіального, безпекового аспектів міжнародної політики інституцій ЄС та країн-учасниць ініціативи "СхП". Виокремлено діяльність інституцій, Фондів ЄС, фрункції громадянського суспільства країн східного партнерства як важливих регіональних чинників у розвитку ініціативи ЄС "СхП". Проаналізовано праці вітчизняних, зарубіжних вчених, політиків інституцій $Є C$ та країн-партнерів "СхП" з акцентом на стрижневих питаннях. Охарактеризовано ключові позиції очільників Єврокомісії, директорату з регіональної політики, Комітету ЄС, Комітету Верховної Ради з питань інтеграції України з ЄС. Опрацьовано напрямки-стратегії, джерела адресного фрінансування відповідних фонддів в контексті регіональних аспектів розвитку ініціативи "СхП". Висвітлено значення самітів, конфреренцій, форумів як практичних фоорм розвитку регіональних аспектів імплементації "СхП". Наведено приклади документальних джерел інституцій ЄС: "Комунікації", "Інформаційне повідомлення", Спільна Декларація ЄК; акти; протоколи ЄПД; звіти, програми: ініціатива ЄС "Чорноморська синергія", Німеччини "ЄПС плюс" (ENP Plus), Програма Франції "Середземноморський Союз". Виокремлено значення діяльності представників урядових, неурядових організацій в Україні, I-IV Форумів громадянського суспільства при ЄС щодо рішень в підтримку аспектів регіонального розвитку, як-от: діяльність кримського регіонального напряму, 2008-2014 рр. - одного з перших в імплементації "СхП", освітні програми в ЗВО, як-от: Львівський національний університет імені Івана Франка, Національний університет "Острозька академія", Ніжинський державний університет імені Миколи Гоголя в Україні. Ключові слова: регіональні аспекти, ініціатива "СхП", інституції, громадянське суспільство, адресні фрінансові фонди, інвестиційні проєкти, комунікації, співпраця, фрорум громадянського суспільства. 
В контексті міжнародної політики Європейського Союзу (далі ЄС) чільне місце посідають регіональні аспекти ініціативи "Східне партнерство" (далі СхП). Їх дослідження $є$ на часі для показу набутого з 2006 р. досвіду суспільно-економічної, соціокультурної, безпекової співпраці інституцій ЄС та країн-учасниць ініціативи "СхП", яка становить органічний концепт регіональної проблематики міжнародної політики ЄС.

3 історії питання та нормативно-документальних джерел інституцій Співдружності відомо, що метою регіональної політики $Є С є$ не вплив на хід європейських процесів, а узагальнення шляхів двосторонніх комунікацій, пошук механізмів для взаємовигідних спільних програм взаємодії між країнами ЄС та партнерами.

Постановка проблеми. Важливість висвітлення регіональної політики ЄС в площині ініціативи "СхП" безперечна. В розрізі аналітики документально-інформаційного, соціо-комунікативного, територіального, безпекового аспектів міжнародної політики країн Співдружності вона поглиблює форми співробітництва шляхом збільшення кількісного складу учасників, зростання інтеграційного потенціалу континенту, перспективного й для України.

Актуальність теми криється в аналізі нормативно-документальних джерел, інвестиційних проєктів, ролі громадянського суспільства, діяльності фондів як важливих регіональних чинників у розвитку ініціативи ЄС "СхП".

Метою є висвітлення аспектів регіональної політики ЄС для країн-учасниць Східного партнерства.

Аналіз останніх досліджень і публікацій. Наукові праці вітчизняних та зарубіжних вчених, політиків інституцій ЄС та країн-партнерів "СхП" становлять важливу складову в дослідженні означеної проблематики. Вони представлені значною кількістю публікацій, серед яких монографії, збірники статей науковців, політиків України, Франції, Бельгії, Німеччини, Польщі, що також свідчить про важливість висвітлення в теоретичній площині практичних здобутків регіональної складової в міжнародній діяльності ЄС.

"Потреби аналітичного дослідження регіональної політики ЄС відповідно обумовлені тією увагою, що приділяють всі інституції Європейського Союзу різним аспектам регіонального розвитку країн Європи". Ствердженням думки $€$ наявність дискурсів "інтегрований регіональний розвиток", "регіональна політика", "політика прикордонного співробітництва ЄС", "внутрішня регіональна політика", "зовнішня регіональна політика", "Південна, Східна регіональні програми". Вони фрормують теоретичні основи тематичних платформ для розвитку регіональних векторів діяльності ЄС. 
Їх сутність ствердив Дірк Анер, Генеральний директор із регіональної політики Європейської комісії (далі ЄК): "Європейська регіональна політика орієнтована на перетворення проблем на можливості". Наголошуючи на розумінні регіонального розвитку як процесу, що потребує дієвих та ефективних інститутів, Дірк Анер аргументує важливість тісної співпраці між урядами, бізнес-організаціями i соціальними групами громадянських суспільств країн-учасниць "СхП". Означені структури стали ключовими в характеристиці регіональних аспектів ініціативи ЄС "СхП" [2, с. 4].

Науковцями України визначено моделі регіональної політики ЄС [11], досліджено досвід регіональної політики Співдружності в проекції на українські реалії [7], стратегічні імперативи для України в контексті регіональної політики ЄС [5]. На прикладі світового та українського досвіду опрацьовано правове регулювання в напрямах регіональної політики (Ткачук).

Серед нових надходжень 2016 р. показовим $є$ підручник-тренінг для тренерів "Модель європейської регіональної політики" за авторством розділів 28-ми науковців та профрінансований за підтримки ЄК ЄС [8].

Наукове підґрунтя досліджень вчених стверджують конференції. Так, 2006 р. у Брюсселі проходила конференція за програмою "Відкриті дні", на якій економіст Майкл Спенс, лауреат Нобелівської премії, наголосив на необхідності проведення діалогів з регіональної політики для розповсюдження досвіду ЄС у сфері регіонального розвитку в країнах світу. Вже у травні 2009 р. в Брюсселі було організовано та проведено Генеральним директоратом з регіональної політики за участю Данути Хебнера, колишнього комісара 3 регіональної політики, конференцію на тему "Регіональне управління у глобальному контексті". "Будучи першою подією такого роду, конференція зібрала президентів європейських регіонів і представників широкого спектру неєвропейських країн [2, с. 15].

Доцільно конкретизувати інформаційний, комунікативний, інвестиційний напрямки як аспекти зовнішньої регіональної політики країнучасниць "СхП" та охарактеризувати кожний в контексті складових ініціативи "СхП", осібно в Україні.

Виклад основного матеріалу. Формулюючи 2009 р. сучасну модель ЄС для інтегрованого регіонального розвитку, Дірк Анер визначив 3 основні напрямки-стратегії: економічне наближення; конкурентоспроможність та зайнятість; форми співпраці для реалізації фрінансовоекономічних інвестицій в галузі економіки, культури, освіти країн-учасниць "СхП", навів 3 основні джерела адресного фрінансування, створені 
у різні часи в розвитку ЄС. Це - Фонд європейського регіонального розвитку (European Regional Development Fund, ERDF), Фонд наближення, Європейський соціальний фронд. Означені економічні стратегії та Фонди, як джерела фрінансування, були спрямовані на підтримку ініціатив, пов'язаних з економічним зростанням, на інвестиції в людський капітал у сфрері освіти і професійної підготовки [2, с. 5]. Гарантом успіху була взаємодія інституцій ЄС та урядів країн-учасниць "СхП" з представниками економіки та бізнесу, з громадянським суспільством.

Наведена структура стратегій, джерел фрінансування, соціоінституційних чинників $€$ визначальними в контексті регіональних аспектів міжнародної політики ЄС. Їх формуванню сприяли задокументовані в нормативно-правових актах, протоколах, рекомендаціях ЄПД історичні факти, серед яких є матеріали Саміту ЄС 1993 р. у Копенгагені. В них було зафріксовано етапи майбутнього розширення $€ C$, програма цивілізаційних перетворень у східному та південносхідному субрегіонах європейського континенту та Звернення "Ширша Європа" ЄК у березні 2003 р. Створенню нормативно-правових угод східно-регіонального розширення $Є С$ впродовж наступних 2004-2007 рр. сприяли дипломатичні (практичні, теоретичні) двосторонні дії представників Інституцій ЄС, України, що підтвердили документальні звіти, програма "Чорноморська синергія", ініціатива Німеччини "ЄПС плюс" (ENP Plus), Програма Франції "Середземноморський Союз", діяльність, зокрема, в Україні, представників державних урядових та неурядових аналітичних організацій.

Як відомо, розвиток регіональних аспектів ініціативи ЄС "СхП" лежить в площині дії ЄПД на 2004-2008 рр., конкретика хронології подій, документальні матеріали якої мають певний резонанс. Документальним свідченням цьому є Повідомлення ЄК "Про заходи з імплементації ЄПС", комунікація від Єврокомісії "Посилення Європейської політики сусідства", директива 2006 р. "Комунікація щодо посилення Європейської політики сусідства", де передбачалося укладання секторальних угод між $Є С$ і країнами $Є П С$ як нових інструментів $Є П С$ та містилися положення про створення тематичних вимірів у ЄПС, Повідомлення для Європарламенту та Ради ЄС "Реалізація Європейської політики у 2007 році". Ключовими в змісті кожного з них були "південний" та "східний" регіональні напрями співпраці. Вони визначені в Програмі "Стратегічні документи з питань ЄПС" як форми співпраці ЄС з Алжиром, Вірменією, Азербайджаном, Білоруссю, Єгиптом, Грузією, Ізраїлем, Йорданією, Ліваном, Лівією, Молдовою, Марокко, Україною, окупованими палестинськими територіями Сирії, Тунісу та дотримуються рівноцінних з засадничим в регіональній політиці $Є С$ 
дефініціям понять, як-от: демократія, права людини тотожні "субсидіарність, децентралізм, партнерство"; принципи ринкової економіки, узгоджені правові норми та правила керування у політичному, безпековому, економічному, соціокультурному векторах співпраці тотожні дефініціями "програмування, концентрація та комплементарність". Їх смислова наповненість характеризується визначенням кінцевої мети ЄПС - поглиблення політичних взаємин та економічна інтеграція. Наведені дефініції регіональної політики як особливого різновиду спільної європейської політики ЄС стали ії невід'ємною складовою.

Як відомо, у 2004, 2007 рр., відбулася п'ята хвиля геополітичного розширення ЄС після приєднання 12 колишніх соціалістичних держав (Кіпр, Естонія, Литва, Латвія, Мальта, Польща, Словаччина, Словенія, Угорщина і Чеська Республіка, Болгарія і Румунія) з набагато складнішою економічною і політичною ситуацією. Втім, П'ята хвиля розширення ЄС стала сприятливою для України в розумінні створення додаткових можливостей, стратегічних перспектив у реалізації інтеграційної політики, підвищення національної та міжнародної стабільності, безпеки та добробуту, можливостей країн-сусідів брати участь у заходах Співдружності.

Втім, на ознаки трансформації "СхП" ЄС в розумінні значущості політики розширення кордонів $Є С$ вказує В. Л. Мартинюк, зазначаючи, що з 2006 р. ЄПС зазнає нових випробувань унаслідок конфліктів між Росією і сусідніми країнами. Це спонукало ЄС звернути увагу на зазначений регіон, переосмислити та адаптувати політику щодо Росії та її східноєвропейських сусідів, що свідчило про потребу нових імпульсів в діях ЄПС [10].

Для прикладу, оновленню ЄПС, її реформуванню сприяла ініціатива Німеччини "ЄПС плюс" (ENP Plus), ідея якої полягала в розвитку секторального співробітництва, з дотриманням двох ключових положень: відповідності секторальним стандартам ЄС та доступу до секторальних програм інституцій ЄС, в переліку яких виокремлені енергетика, транспорт, навколишнє середовище, охорона здоров'я, розвиток регіонів, інформаційне суспільство, співробітництво в наукових дослідженнях, фрінансова служба, управління кордонами, оборонна та безпекова політика, міграція, морське сполучення. Було започатковано також програму "Чорноморська синергія" як окремого формату для розбудови регіональної співпраці, необхідності диференційованого підходу в реалізації політики розширення з урахуванням регіональних особливостей південного й східного напрямів ЄПД. У травні 2007 р. за ініціативи Президента Франції Н. Саркозі було сформовано "Середземноморський союз", згодом трансформований 
у "Союз для Середземномор'я", програму якого було прийнято в березні 2008 р. на засіданні $Є Р$, як ствердження значення регіональної діяльності ЄС. Активну позицію щодо розвитку східного напрямку в зовнішній політиці $Є С$ демонструвала Польща.

Складовою міжнародно-правових передумов прийняття ініціативи ЄС "СхП" слугував Саміт у Брюсселі 20 червня 2008 р., у Програмі якого було зосереджено увагу на ухваленні $Є Р$ пропозиції щодо розробки східного напряму в двосторонньому та багатосторонньому форматах, й у травні 2009 р. в Комітеті ЄС з економічних та соціальних питань були озвучені постанови про "Залучення громадянського суспільства до "Східного партнерства" й "Залучення громадянського суспільства до впровадження планів дій у рамках ЄПС у країнах Південного Кавказу: Азербайджану, Вірменії та Грузії" [3, с. 23].

Слід підкреслити, що після офріційного запровадження $€ C$ ініціативи "СхП" діяльність європейських інституцій та установ країн-учасниць, згідно з задекларованими ініціативами-фрлагманами та тематичних платформами, розвивалася у формі діалогу. При співробітництві урядів особлива увага надавалася взаємозв'язку з усіма групами суспільства. Ці положення $є$ спорідненими з аспектами регіональної політики ЄС, в якій Дірк Анер виокремлює сильне інституціональне лідерство, що вимагає поваги до всіх частин суспільства на всіх рівнях та ефрективну політичну систему [2, с. 4]. Ствердженням даної тези є громадянське суспільство як соціально ефективний, політично незалежний чинник кожної країни-учасниці "СхП", вмотивований створенням й розвитком сприятливого для громадських організацій країни середовища в запровадженні ініціативи "СхП". Діяльність громадських, неурядових організацій сприяла розвитку вище згаданого базового принципу партнерства в регіональній політиці ЄС.

3 історії питання, записів у нормативно-документальних джерелах ("Комунікації", Спільна Декларація ЄК від 7 травня 2009 р.) відомо, що неурядовим організаціям (НУО) з метою підтримки подальшого розвитку громадянського суспільства пропонувалося зареєструватися в загальну базу даних для участі у громадянській сфері. Цьому сприяла й проведена 05-06 травня 2009 р. в Празі під головування Чехії пілотна конференція "Східне партнерство: назустріч Форуму громадянського суспільства". Згодом в "Інформаційному повідомленні" ЄК від 13 листопада 2009 р. зверталася увага на створення відділу "Регіональний моніторинг та підтримка" для посилення впливу на програми регіональної співпраці.

Дискусії на конференції проводились за широким спектром тематик по всіх платформах. Їх результатом стали Політичні рекомендації 
для саміту "СхП" (Policy Recommendations for Eastern Partnership Summit) з залученням громадянських організацій до процесу імплементації "СхП", реалізації її двостороннього, багатостороннього вимірів. 3 цією метою було створено Форум громадянського суспільства (ФСГ) для посилення взаємодії між громадянськими суспільствами країн-учасниць ініціативи "СхП" й державами-членами ЄС для забезпечення поступового зближення у сфрерах демократії, належного державного управління, стабілізації й налагодження міжнародних контактів, досягнення економічної інтеграції, енергетичної безпеки, соціокомунікацій. До участі в ньому вже 3 вересня 2009 р. ЄК отримала 439 заяв, серед яких від Грузії - 30, Вірменії - 50, Азербайджану - 69, Білорусі - 76, Молдови - 30, України - 62, від держав-членів ЄС й міжнародних мереж - 122.

Перший ФСГ "СхП" проходив 16-17 листопада 2009 р. у Брюсселі за участю 141-ої громадської організації з країн-учасниць "СхП", 79 організацій з країн ЄС, інших держав й працював за принципом тематичних платформ багатостороннього виміру "СхП". 3 цією метою було створено тематичні робочі групи, які працювали паралельно з відповідними міжурядовими тематичними платформами. На офріційному сайті Національної платформи ФГС зазначено, що це - багатонаціональна платформа організацій громадянського суспільства з країн "СхП", країн-членів ЄС, європейських та міжнародних мереж, створена для участі громадянського суспільства в розробці, впровадженні та оцінці "СхП", розвитку міжпарламентського співробітництва в рамках "EuroNest" як складової "СхП", що становив новий аспект регіональної політики ЄС. Як зазначила Беніта Ферреро Вальднер - Комісар ЄС 3 питань зовнішніх зносин та ЄПД, "форум надасть свіжі ідеї, оскільки наша робота спрямована на потреби країн-партнерів" [1].

У ході проведення III ФГС у Познані 28-30 листопада 2011 р. реєстр НУО сягав вже 300 організацій, до яких долучилися неурядові структури з ЄС: Польщі, Німеччини, Швеції. Виступаючи перед учасниками Ш. Фюле, Єврокомісар з питань розширення та ЄПД, наголосив: "Для громадських організацій необхідно співпрацювати з "усіма стейкхолдерами" у своїх країнах, а також налагодити тісні партнерські стосунки з організаціями інших країн регіону, обмінюватися знаннями та досвідом. Ключова діяльність повинна бути сконцентрована в рамках однієї національної платформи від кожної з країн-учасниць.

На познанському Форумі було створено Фонд громадянського суспільства, спрямований на фінансову підтримку спільних ініціатив неурядового сектору. Так, на 2011-2013 рр. цей Фонд виділив 65 мільйонів євро для країн-сусідів. 
Напередодні IV ФГС 19 вересня 2012 р. ЄК оприлюднила повідомлення "Коріння демократії та стабільного розвитку: тісніші стосунки Європи з громадянським суспільством у рамках зовнішніх відносин", з матеріалів якого очевидно, що ЄК визнала організації громадянського суспільства, й запропонувала запустити "Дорожні карти ЄС" для більш активного залучення інституцій Союзу в співпраці з організаціями громадянського суспільства. Це допомагало Представництвам ЄС в країнах Європи мати більш структуровану та стратегічну співпрацю 3 громадянським суспільством будь-якої країни.

Про актуальність регіональних аспектів "СхП" зазначено в Повідомленні Європейської Комісії: "Україна включена в європейські регіональні процеси через Європейську політику Добросусідства (ЄПД), у межах якої, починаючи з 2006 р., почала приділятися особлива увага розвитку східного регіонального співробітництва" [8, с. 10]. Одним з перших напрямів імплементації в Україні ініціативи ЄС "СхП" став кримський. Залучення Автономної республіки (далі - АР) Крим до даної ініціативи ЄС було знаковим, оскільки поглиблювало вже розпочату на півострові з 2008 р. діяльність міських молодіжних євроклубів. На його впровадження була спрямована робота Представництва ЄС в Україні, Міністерства закордонних справ України в Сімферополі АР Крим, що свідчило про початок імплементаціі в Україні ініціативи ЄС "СхП" в контексті регіональної співпраці. Прагнення країн-членів ЄС реалізувати в АР Крим фооми ініціативи "СхП" свідчило про розуміння та врахування ними національних, регіональних, мікрорегіональних особливостей цього регіону України [4, с. 254]. Втім, політичні події 2013-2014 років, зокрема Революція Гідності на Хрещатику в Києві, як шлях повернення України до демократичних основ розвитку суспільства, анексія Росією АР Крим у березні 2014 р., привели восени того ж року до призупинення надання до АР Крим інвестицій структурами ЄС.

Важливою формою впровадження регіонального співробітництва ініціативи ЄС "СхП" стала Парламентська Асамблея "Євронест" (EURONEST Parliamentary Assembly). Цьому сприяли різнорівневі зустрічі; робочі, пленарні засідання; комітетські слухання, нормативно-документальні джерела, представлені Управлінською документацією Комітету з питань європейської інтеграції ВР України, що дає панораму становлення та розвитку Парламентської Асамблеї "Євронест", розкриває ії значущість в активізації регіональних аспектів взаємодії парламентів країн-учасниць ініціативи ЄС "СхП".

У контексті співпраці інституцій ЄС впродовж 2000-х років з урядами та НУО країн-учасниць "СхП" було підготовлено 58 проєктів ЄС 
Східного регіону з напрямків культури, клімату, цифрової безпеки, бізнесу, дозвілля, екології, самоврядування, молоді, серед яких Проєкт Business EU4: Служба підтримки торгівлі зі східного партнерства (2019-2024) з бюджетом 3,7 мільйонів євро, спрямований на підтримку збільшення торгівлі між країнами-партнерами Східної Європи та з ЄС шляхом надання онлайн-порталу, який пропонує доступ до торговельної інформації з регіональної точки зору; Проєкт EU4Youth - Дорожні карти щодо залучення молоді (2020-2021) 3 бюджетом 1,8 мільйонів євро для розвитку національної молодіжної політики залученням молоді з регіону країн-східних партнерів до громад великих та малих міст, селищ. Для розбудови інститутів, що підтримує країни-партнери через інституційне співробітництво, напрацьований як довгостроковий інструмент Проєкт Twinning (20142020). В рамках проєкту "European Values and Identity Studies" 3 бюджетом Програми Еразмус+ на 2014-2020 роки в 14,7 мільярдів євро сплановано взаємодію з понад 150 країнами світу, серед яких мають комунікації з програмою заклади вищої освіти України, як-от Львівський, Ніжинський, осібно, Національний університет "Острозька академія" (м. Острог), де онлайн 15 травня 2020 р. відбулася XIII наукова конференція "Проблеми культурної ідентичності в ситуації сучасного діалогу культур".

Висновки. Таким чином, ініціатива "СхП" як сукупність збалансованих нормативно-документальних принципів, тематичних платформ інституцій ЄС і країн-учасниць становить важливий концепт регіональних аспектів міжнародної політики Співдружності. У контексті причинно-наслідкових зв'язків їх багатосторонні комунікації в імплементації інвестиційних проєктів доцільно розглядати як важливу ознаку східно-регіонального розширення $€ С$, що в політичному аспекті забезпечуватимуть принципи солідарності та субсидіарності, в економічному - зростання інтеграційного потенціалу в енергетичній, екологічній галузях, транспортному, транскордонному співробітництві, розвитку міжкультурних зв'язків громадянських суспільств країн ЄС та східних партнерів ініціативи "СхП".

\section{Література}

1. Відбувся Форум громадянського суспільства Східного партнерства. Євробюлетень. 2009. № 12 (грудень). С. 11.

2. Європейська регіональна політика: натхнення для країн, що не входять до ЄС? Застосування принципів та обмін досвідом / Office of the official publications of the European Union. Luxembourg, 2009. 16 c. URL: https://ec. europa.eu/regional_policy/sources/docgener/presenta/international/external_uk.pdf (дата звернення: 13.05.2020). 
3. ЄЕСК долучається до реалізації Східного партнерства. Євробюлетень. 2009. № 6 (червень). С. 23.

4. Кавунник А. Л. Кримський напрям ініціативи $€ С$ "Східне партнерство". Наш Крим=Our Crimea/за матеріалами Першої Міжнародної наукової консреренції "Крим в історії України", присвяченої 700-літтю спорудження мечеті хана Узбека в Старому Криму / за ред. Д. С. Гордієнка та В. В. Корнієнка. Київ, 2015. Вип. 1. С. 246-254.

5. Кіш $€$. Регіональна політика Європейського Союзу: стратегічні імперативи для України. Незалежний культурологічний часопис "ї". 2002. № 23. C. $133-157$.

6. Наши соседи: панорама региональных программ и проектов в странах Восточной Европы / Европейская Комиссия, Бюро сотрудничества EuropeAid. Брюссель, 2010. 56 с.

7. Прокопенко Л. Л. Розвиток регіонального співробітництва України в контексті європейської інтеграції: монографрія. Дніпро, 2008. 132 с.

8. Регіональна політика Європейського Союзу: підручник / за ред. Віктора Чужикова. Київ: КНЕУ, 2016. 495 с.

9. Регіональна політика: правове регулювання. Світовий та український досвід / за заг. ред. Р. Ткачука. Київ, 2010. 224 с.

10. Східне партнерство Європейського Союзу: додаткові можливості для інтеграції України / І. Ф. Газізуллін, М. М. Гончар, О. В. Коломієць та ін.; за ред. В. М. Мартинюка; Український незалежний центр політичних досліджень. Київ, 2009. 84 с.

11. Тихомирова $€$. Б. Моделі регіональної політики $€$. URL: http://vmv. kymu.edu.ua/v/p03/p053.pdf (дата звертання: 27.04.2020).

\section{References}

1. Chuzhykov V. (Eds.). (2016). Rehionalna polityka Yevropeiskoho Soiuzu [Regional Policy of the European Union] Kyiv [in Ukraine].

2. Hule R. (Eds.). (2009). Yevropeiska rehionalna polityka: natkhnennia dlia krain, shcho ne vkhodiat do YeS? [European regional policy: inspiration for nonEU countries?] / Office of the Official Publications of the European Union URL: https://ec. europa. eu/regional_policy/sources/docgener/presenta/international/ external_uk. pdf (Last accessed: 13. 05. 2020) [in Ukrainian].

3. leESK doluchaietsia do realizatsii Skhidnoho partnerstva (2009) [EESC joins the realization of Eastern Partnership] Yevrobiuleten - Eurobulletin. (6) 23 [in Ukraine].

4. Kavunnyk A. L. (2015). Krymskyi napriam initsiatyvy YeS "Skhidne partnerstvo" [Crimean direction of the EU initiative "Eastern Partnership"]. Nash Krym - Our Crimea. Kyiv. 246-254 (Vol. 1) [in Ukraine].

5. Kish E. (2002). Rehionalna polityka Yevropeiskoho Soiuzu: stratehichni imperatyvy dlia Ukrainy [Regional policy of the European Union: strategic imperatives for Ukraine] Nezalezhnyi kulturolohichnyi chasopys "İ". (23). 133-157. Independent cultural journal "İ" [in Ukraine].

6. Martynyuk V. M. (Eds.). (2009) Skhidne partnerstvo Yevropeiskoho Soiuzu: dodatkovi mozhlyvosti dlia intehratsii Ukrainy [EU Eastern Partnership: Additional Possibilities for integrating Ukraine] Kyiv [in Ukraine]. 
7. Nashy sosedy: panorama rehyonalnykh prohramm y proektov $v$ stranakh Vostochnoi Evropy (2010) / Evropeiskaia Komyssyia, Biuro sotrudnychestva EuropeAid [Our neighbors: a panorama of regional programs and projects in Eastern Europe] Brussels [in Russian].

8. Prokopenko L. L. (2008). Rozvytok rehionalnoho spivrobitnytstva Ukrainy v konteksti yevropeiskoi intehratsii [Development of regional cooperation of Ukraine in the context of European integration] Dnipro [in Ukraine].

9. Tkachyk R. (Eds.). (2010). Rehionalna polityka: pravove rehuliuvannia. Svitovyi ta ukrainskyi dosvid. [Regional policy: legal regulation. World and Ukrainian experience]. Kyiv.

10. Tykhomyrova Ye. B. Modeli rehionalnoi polityky YeS [Models of EU regional policy] URL: http://vmv. kymu. edu. ua/v/p03/p053. pdf (Last accessed: 27. 04. 2020) [in Ukraine].

11. Vidbuvsia Forum hromadianskoho suspilstva Skhidnoho partnerstva (2009) [The Eastern Partnership Civil Society Forum was held] Yevrobiuleten - Eurobulletin. (12) 11 [in Ukraine].

\section{A. L. Kavunnyk}

$\mathrm{PhD}$ student, M. S. Hrushevsky Institute of Ukrainian Archeography and Source Studies of the National Academy of Sciences of Ukraine

ORCID: 0000-0003-4920-2327; e-mail: kavunnyk.a@gmail.com

\section{Regional aspects of the European Union's international policy in the context of the Eastern Partnership}

The present article deals the regional aspects of the international policy in the context of historical facts from the past and present of Ukraine, the countries participating in the EU's Eastern Partnership initiative. In the article have been investigated of documentary sources, socio-communicative, territorial, security aspects of the international policy of the EU institutions and the countries participating in the "EaP" initiative has been approved. The activity of institutions, EU Funds, functions of civil society of the Eastern Partnership countries as important regional factors in the development of the $E U$ initiative "EaP" are highlighted. Analyzed scientific articles, monografie the ukrainian and foreign scientists, politicians of the EU institutions and Eastern partnership countries with an emphasis on core issues. The paper studies the key positions of the heads of the European Commission, the Directorate for Regional Policy, the EU Committee, the Verkhovna Rada Committee on Ukraine's Integration with the EU are characterized. A more thorough study the directions-strategies, sources of targeted financing of the corresponding Funds in the context of regional aspects of development of the initiative "EaP".

The importance of Summits, Conferences, Forums as practical forms of development of regional aspects of implementation of "EaP" is highlighted. For the examples of documentary sources of EU institutions are given: "Communications", "Recommendation", EU' Joint Declaration; Acts; ENP protocols; Reports, programs: EU initiative "Black Sea Synergy", Germany "ENP Plus" (ENP Plus), France's program "Mediterranean Union". A general conclusion is made concerning about the activities of representatives of governmental and non-governmental organizations in Ukraine, I-IV Civil Society Forums at the EU on decisions in support of aspects of regional development, such as: Crimean regional activities, 20082014 - one of the first in the implementation of "EaP", educational programs in institutions of higher education in Ukraine, such as: Ivan Franko Lviv National University, National University "Ostroh Academy", Mykola Gogol Nizhyn State University .

Key words: regional aspects, the East initiative, institutions, civil society, targeted financial funds, investment projects, communications, cooperation, civil society forum. 